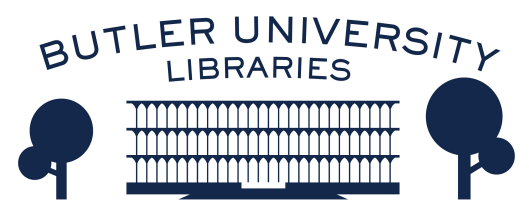

Journal of Hindu-Christian Studies

Volume 9

Article 19

January 1996

\title{
Book Review: "Die Symbolik von Gift und Nektar in der klassischen indischen Literatur"
}

Anand Nayak

Follow this and additional works at: https://digitalcommons.butler.edu/jhcs

Part of the Religion Commons

\section{Recommended Citation}

Nayak, Anand (1996) "Book Review: "Die Symbolik von Gift und Nektar in der klassischen indischen Literatur"," Journal of Hindu-Christian Studies: Vol. 9, Article 19.

Available at: https://doi.org/10.7825/2164-6279.1141

The Journal of Hindu-Christian Studies is a publication of the Society for Hindu-Christian Studies. The digital version is made available by Digital Commons @ Butler University. For questions about the Journal or the Society, please contact cbauman@butler.edu. For more information about Digital Commons @ Butler University, please contact digitalscholarship@butler.edu. 
importance of this volume. It is an invaluable and well-documented source of information for anyone interested in Rammohun's controversies with Hindu traditionalists, Christians, and Unitarians, and therefore an important addition to research on interreligious dialogue in modern India. I is also one of the clearest expositions to date of the development of Rammohun's own thinking.

Ronald Neufeldt

Professor of Religious Studies

University of Calgary

\section{Die Symbolik von Gift und Nektar in der klassischen indischen Literatur. Ira Stubbe-Diarra. Wiesbaden: Harrassowitz Verlag (Studies in Oriental Religions, vol. 33), 1995, xii+154 pp.}

POISON (HALÄHALA, OR Kälakuta) and nectar (amrta) are the two ever recurring mythical beverages whose antagonistic symbolism in the Hindu religious world exceeds their mythological boundaries. This is the main thesis that Ira Stubbe-Diarra develops in her interesting and painstaking study. These drinks - the one deathprovoking and the other life-bringing, the unholy and the holy, the evil and the good have brought about numerous philosophical and hermeneutical discussions in the Hindu literature. After a brief reconstruction of the fundamental myth of the churning of the ocean (samudramathana) as found in several puranic and epic texts, Stubbe-Diarra presents the halähala-amrta symbolism through a rich analysis of numerous texts. This detailed and phenomenological enquiry covers all major purānas, the Rāmāyana and the Mahābhārata and some tantric texts.

Poison in Hindu mythology is seen not only as the deadly secretion which rose up and which was swallowed up by the serpents (naga) at the churning of the ocean, but also as the substance forming the strength of the warrior, fuelling in him anger and hate. It is the wily energy of the witch as well as the enslaving power of ignorance and delusion. It can be neutralized or washed away and even harnessed only through higher divine agents like the bird Garuda, the sages, or through mantras and yogic powers.
Nectar brings not only life but life everlasting, immortality. Closely linked to the early vedic drink soma, it is further brought in relationship with the moon (soma), causing the principle of life to wax and wane. This force of life is seen also in the sun, in fire, in plants, and in water, notably in the Ganges, the heavenly flow of the primordial life-giving waters. The cow is full of nectar and imparts it to beings through her milk and urine. Life-giving semen too is nectar.

Stubbe-Diarra attempts an interpretation of these symbols (pp. 2, 142). According to her, Hinduism expresses through these symbols the dual conflicting forces of evil and good, death and life. However, these forces are not necessarily contradictory. Knowledge and a disciplined practice of yoga can overcome the deadly effects of poison and make it subservient to life (p.137).

We have here a handy work that makes available a variety of texts on the theme, accurately presented, bringing out deeper meanings of the symbols in question. The textual compilation is the strength of this work. Its weakness lies perhaps in the absence of an adequate methodology of interpretation. The mythical and the tantric expressions not being the same, they cannot be put on the same level of interpretation. The frequent quotations from English 
translations of the puranic and epic texts in a German work is also to be regretted.
Anand Nayak

University of Fribourg, Switzerland

\section{Gandhi and His Jewish Friends. Margaret Chatterjee. London:} Macmillan, 1992, xiv +182 pp.

\begin{abstract}
ALTHOUGH THERE IS little reference to Judaism in Gandhi's Collected Works, Margaret Chatterjee demonstrates that Gandhi had many Jewish friends and that they were an important influence on his life and thought. As such this volume is a useful addition to her earlier Gandhi's Religious Thought (Macmillan, 1983). It also brings attention to a formative influence in Gandhi's thought that has not previously been examined.
\end{abstract}

While in South Africa, Gandhi sought to enlist European help in his fight for the cause of immigrant Indians. Chatterjee shows that most of Gandhi's close friends and supporters during his South African period were Jewish. As Gandhi himself put it, "In South Africa, I was surrounded by Jews" (p.105). She suggests that their willingness to assist Gandhi was because they knew well from their own experiences the injustices immigrants experience. Equally important, suggests Chatterjee, was the fact that many of them were theosophists rather than observant Jews, and Theosophy also attracted Gandhi during his South Africa period. They participated with Gandhi in his early experiments with community economic life on the 100-acre Phoenix Settlement outside of Durban inspired by the reading of Ruskin's Unto This Last. They also gave Gandhi a LondonJohannesburg link to mobilize support for the Indian cause in South Africa. At the Phoenix Settlement many of Gandhi's ashram ideas are prefigured: co-educational schooling, emphasis on manual labour, opposition to industrialization, ahimsa, and the practice of brahmacharya. Chatterjee observes, "Hind Swaraj was yet to be written. But much of it was surely in Gandhi's mind during those early days at Phoenix" (p.65).

Christian influence also came to Gandhi's community experiments via Tolstoy. With the help of his Jewish friend Kallenbach, 1100 acres was purchased and a Tolstoy Farm established where satyagrahi families could lead a religious life (p.79). Different religions lived together with men and women housed separately and the women referred to as "sisters" which, suggests Chatterjee, was arrived at by Gandhi's combining of "the Gujarati custom of adding the word 'behn' (sister) to the names of women and the name for those who have taken vows in Christian convents". The difficult spartan life at Phoenix and the Tolstoy Farm evolved in Gandhi's mind as a training ground for satyagrahis who would be effective soldiers of non-violence. Thus the Jewish-supported South African experiments in community living pioneered Gandhi's prerequisite requirements for engaging in effective political activity (p.87). It was here that Gandhi's ideas of a community founded on truth, chastity, poverty, tolerance, and physical labour were hammered out.

In discussing Gandhi's interaction with Judaism during the World War II years, Chatterjee's research turns up interesting findings. Chatterjee convincingly shows that in spite of having ample evidence regarding the fate of the Jews in Germany, Gandhi was unable to understand the Jewish fear of annihilation in the face of Hitler's program of genocide. Chatterjee's strong conclusion is that in this situation, Gandhi was guilty of "moral blindness" (p.119). His flaw was his 